\title{
Analisis Rasio Likuiditas, Solvabilitas, Profitabilitas, dan Aktivitas untuk Menilai Kinerja Keuangan Koperasi Sejahtera
}

\author{
Analysis of Liquidity, Solvability, Profitability, and Activity Ratio to Assess \\ the Financial Performance of the Sejahtera Cooperative
}

\author{
Aslama Ramdhani, Elmanizar \\ Accounting Study Program, Faculty of Economics and Business, YARSI University, Jakarta \\ Jalan Letjen. Suprapto, Cempaka Putih, Jakarta 10510 \\ Telepon (021) 4206674, 4206675, 4206676 \\ E-mail:elmanizar@yarsi.ac.id
}

KEYWORDS liquidity, solvability, profitability, activities, financial performance

ABSTRACT This study aims to determine the financial performance of Sejahtera Cooperative period 2012-2016 measured by aspects of liquidity, solvability, profitability, and activity. This study uses secondary data from financial reports obtained from the Sejahtera Cooperative. This study uses quantitative methods with descriptive format. The results from this study showed cooperative financial performance based on the aspect of likuidity ratio is considered very unhealthy. Cooperative financial performance based on the aspect of solvability ratio is considered healthy. Cooperative financial performance based on the aspect of profitability ratio is considered unhealthy. Cooperative financial performance based on the aspect of activity ratio is considered very unhealthy.

\section{PENDAHULUAN}

Di Indonesia koperasi berperan penting dalam menggalang ekonomi bangsa. Selain berperan sebagai ekonomi rakyat, koperasi mencerminkan perwujudan masyarakat yang bergotong royong dalam suatu sistem demokrasi di Indonesia. Berhasil tidaknya suatu koperasi tergantung pada bagaimana para anggotanya untuk mau bekerjasama dan beraktivitas dibawah pimpinan manajer untuk mencapai tujuan diadakan nya koperasi, dan semua aktivitas tersebut akan tercatat/terangkum dalam Laporan Keuangan.

Menilai laporan keuangan pada koperasi penting dilakukan untuk dapat mengetahui sejauh mana kinerja keuangan koperasi sebagai ukuran untuk melihat keberhasilan manajemen dan pengurus koperasi dalam mengelola koperasi. Menurut Fahmi (2014) kinerja keuangan adalah suatu analisis yang dilakukan untuk melihat sejauh mana suatu perusahaan telah melaksanakan dengan menggunakan aturan-aturan pelaksanaan keuangan secara baik dan benar sedangkan menurut Jumingan (2011) kinerja keuangan merupakan gambaran kondisi keuangan perusahaan pada suatu periode tertentu diukur dengan indikator kecukupan modal, likuiditas, dan profitabilitas perusahaan. Menurut Subranyam dan Wild (2010) analisis rasio (ratio analysis) merupakan salah satu alat analisis keuangan yang paling 
popular dan banyak digunakan. Beberapa Rasio keuangan yang dapat digunakan untuk mengukur kemampuan kinerja keuangan antara lain: rasio likiuditas, rasio solvabilitas, rasio profitabilitas, dan rasio aktivitas, dengan penjelasan sebagai berikut Van Horne dan Wachowicz (2012):

1. Rasio Likuiditas adalah rasio untuk mengetahui kemampuan suatu perusahaan untuk memenuhi kewajiban jangka pendek pada saat jatuh tempo. Rasionya terdiri dari: Current Ratio, Quick Ratio dan Cash Ratio.

2. Rasio Solvabilitas adalah rasio yang dapat mengetahui kemampuan perusahaan untuk memenuhi kewajiban keuangan jangka pendek maupun jangka panjang. Rasio Solvabilitas antara lain: Debt to Asset Ratio (DAR) dan Debt to Equity Ratio (DER) rasio total hutang terhadap ekuitas/modal sendiri.

3. Rasio Profitabilitas adalah rasio yang mengetahui kemampuan perusahaan untuk menghasilkan laba selama periode tertentu. Rasio profitabilitas yang digunakan, antara lain:

Net Profit Margin (NPM), dan Return on Asset (ROA) serta Return on Equity (ROE)

4. Rasio Aktivitas adalah rasio yang dapat mengukur kemampuan perusahaan dalam mengelola sumber dana untuk meningkatkan produktivitas usaha dalam memaksimalkan nilai perusahaan. Rasio aktivitas yang dapat digunakan yaitu Receivable Turn Over perputaran piutang yaitu perbandingan antara penjualan atau pendapatan dengan rata-rata piutang dalam satu peride.
Penelitian ini dilakukan pada Koperasi Sejahtera Karyawan Rumah Sakit Swasta di Jakarta Pusat yang merupakan suatu badan usaha, yang berperan aktif dalam membangun dan mengembangkan potensi dan kemampuan financial anggota/ karyawan untuk meningkatkan kesejahteraan ekonomi dan sosialnya, koperasi ini mulai beroperasi tahun 1982 dengan jumlah modal kurang lebih Rp25.000.000,- Perkembangan modal koperasi lima tahun terakhir ini mengalami pasang surut yaitu, jumlah modal di tahun 2012 sejumlah Rp19.296.311.000,- dan di tahun 2016 modalnya turun jumlah nya menjadi Rp 18.917.537.300, penurunan sejumlah Rp.378.773.700,-. Dengan berlakunya peraturan Menteri Negara Koperasi dan UKM Republik Indonesia Nomor 06/Per/M.KUKM/V/2006 tentang standar pengukuran rasio likuiditas, rasio solvabilitas, rasio profitabilitas, dan rasio aktivitas untuk menilai kinerja keuangan koperasi maka fenomena naik turunnya modal koperasi jika dikaitkan dengan peraturan ini menarik untuk diteliti bagaimana Kinerja Keuangan Koperasi Sejahtera Karyawan Rumah Sakit Swasta di Jakarta Pusat Tahun 2012-2016 dari Aspek rasio likuiditas, solvabilitas, profitabilitas, dan aktivitas.

\section{METODOLOGI}

\section{Jenis Penelitian}

Jenis penelitian ini deskriptif, metode kuantitatif yaitu menganalisis dan mendeskripsikan data-data laporan keungan untuk menilai kinerja keungan dengan rasio likuiditas, solvabilitas, profitabilitas, dan aktivitas. 


\section{Data Penelitian}

Jenis data yang digunakan adalah data sekunder yaitu data yang diambil dari laporan keuangan koperasi periode 2012 sampai 2016, sumber data yang tidak langsung memberikan data kepada pengumpul data (Sugiyono, 2012).

\section{Variabel Penelitian}

Variabel indipenden dalam penelitian ini adalah rasio likuiditas, rasio solvabilitas,ratio profitabilitas dan rasio aktivitas, sedangkan variabel dependen nya adalah kinerja keuangan. Berikut ini defenisi operasional variabel adalah sebagai berikut (Peraturan Mentri Negara Koperasi UKM RI Nomor 06/Per/M.KUKM/2006) :

\section{Rasio Likuiditas}

a. Rasio lancar (current ratio)

Rasio lancar merupakan ukuran kemampuan perusahaan dalam membayar liabilitas jangka pendeknya. Current ratio 06 dirumuskan:

$$
\text { Aset Lancar }
$$

Liabilitas Lancar x $100 \%$

b. Rasio cepat (quick ratio)

Rasio ini menunjukan kemampuan aktiva lancar yang paling liquid mampu menutupi utang lancar.

Rasio cepat dihitung dengan rumus berikut

Aset Lancar - Persediaan

Liabilitas Lancar

c. Rasio Kas (Cash Ratio)

Rasio Kas (Cash Ratio) merupakan alat yang digunakan untuk mengukur seberapa besar uang kas yang tersedia untuk membayar utang. Rumus untuk mencari rasio kas (cash ratio) dapat digunakan sebagai berikut :

$$
\frac{\text { Kas + Bank }}{\text { Liabilitas Lancar }} \times 100 \%
$$

\section{Rasio Solvabilitas}

a. Rasio total utang terhadap asset (Debt to Asset Ratio)

Rasio yang digunakan untuk mengukur sejauh mana utang dapat ditutupi oleh aset.

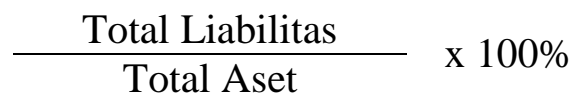

b. Rasio total utang terhadap ekuitas (Debt to Equity Ratio)

dirumuskan:

$$
\frac{\text { Total Liabilitas }}{\text { Modal Sendiri }} \times 100 \%
$$

\section{Rasio Profitabilitas}

a. Net Profit Margin

Rasio ini menggambarkan besarnya laba bersih yang diperoleh oleh perusahaan pada setiap penjualan yang dilakukan. Net profit margin dirumuskan:

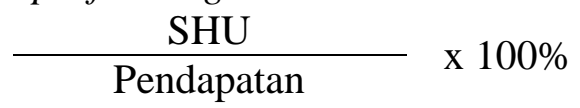

\section{b. Return on Assets (ROA)}

Merupakan satu bentuk dari rasio rentabilitas yang dimaksudkan untuk mengukur kemampuan koperasi dengan keseluruhan dana yang ditanamkan dalam aset yang digunakan untuk operasinya untuk memperoleh Sisa Hasil Usaha. Return on asset dirumuskan:

$$
\frac{\text { SHU }}{\text { Total Aset }} \times 100 \%
$$

c. Return on Equity (ROE)

Merupakan rasio yang membandingkan antara Sisa Hasil Usaha dengan jumlah Modal Sendiri. Return on equity dirumuskan:

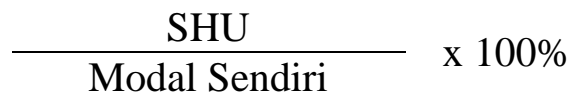


Aktivitas

Rasio aktivitas meliputi rasio perputaran piutang atau Receivable Turn Over, rasio ini mengukur berapa banyak suatu perusahaan dapat mengubah piutangnya menjadi kas selama suatu periode tertentu. Rasio perputaran piutang menurut Peraturan dirumuskan:

Pendapatan

Rata - rata piutang

Rata-rata piutang $=$

piutang awal tahun + piutang akhir tahun

Dalam memperoleh data-data

penelitian ini, penelitiannya

menggunakan teknik pengumpulan data sebagai berikut:

a. Penelitian Kepustakaan (Library

Research)

Penelitian ini langsung melihat pada buku-buku, jurnal, artikel, maupun hasil laporan penelitian terdahulu yang terkait dengan permasalahan yang diteliti.

b. Dokumentasi

Studi dokumentasi dilakukan di Koperasi Sejahtera Karyawan Rumah Sakit Swasta di Jakarta Pusat, peneliti mengumpulkan data-data yang didapatkan dari laporan keuangan periode 2012-2016. Metode analisis data dalam
penelitian perbandingan satu akun dengan akun lain nya dari laporan keuangan koperasi untuk mendapatkan rasio: likuiditas, solvabilitas, profitabilitas, dan rasio aktivitas, hasil nya dibandingkan dengan standar penilaian/peraturan Menteri Koperasi dan UKM Republik Indonesia No.06/Per/M.KUKM/V/2006. Untuk melihat kinerja keuangan koperasi sudah sesuai standar atau masih dibawah standar.

\section{ISI}

Rasio Lancar (Current Ratio)

Adapun standar pengukuran current ratio berdasarkan Peraturan Koperasi berikut ini:

Tabel 1. Standar Pengukuran Current Ratio

\begin{tabular}{ll}
\hline Standar & Kriteria \\
\hline $200 \%$ s/d 250\% & Sehat \\
$175 \%$ s/d $<200 \%$ & Cukup Sehat \\
$150 \%$ s/d $<175 \%$ & Kurang Sehat \\
$125 \%$ s/d $<150 \%$ & Tidak Sehat \\
$<125 \%$ atau & Sangat Tidak \\
$>250 \%$ & Sehat \\
\hline Sumber: PMK No.06/Per/M.KUKM/V/2006
\end{tabular}

Berikut rasio lancar Koperasi Karyawan Sejahtera Tahun 2012-2016 berdasarkan hasil perhitungan current ratio sebagai berikut:

Tabel 2. Kinerja Keuangan Berdasarkan Rasio Lancar

\begin{tabular}{lll}
\hline Tahun & Rasio & Keterangan \\
\hline 2012 & $733,21 \%$ & Sangat Tidak Sehat \\
2013 & $558,29 \%$ & Sangat Tidak Sehat \\
2014 & $655,97 \%$ & Sangat Tidak Sehat \\
2015 & $1063,60 \%$ & Sangat Tidak Sehat \\
2016 & $1266,25 \%$ & Sangat Tidak Sehat \\
\hline \multicolumn{2}{l}{ Sumber: Data diolah }
\end{tabular}

Berdasarkan Tabel 2 dapat dilihat Current Ratio koperasi adalah "sangat tidak sehat" selama tahun penelitian. Penyebab nya adalah perbandingan aset lancar dan utang lancar yang jumlahnya terlalu tinggi, hal ini disebabkan jumlah piutang yang terlalu tinggi dan pengembalian nya dalam jangka waktu yang lama, sehingga aset lancar tidak produktif.

Penelitian yang dilakukan oleh Zulfany (2016) pada Koperasi Arrahmah 
menghasilkan analisis rasio lancar selama kurun waktu 2012-2015 memiki rata-rata $85,12 \%$, yang berarti sangat tidak sehat menurut standar koperasi, karena terlalu rendah ratio nya.

Koperasi Sejahtera memiliki rasio lancar yang lebih tinggi dibandingkan dengan rasio hasil penelitian terdahulu, tetapi sama-sama berada pada area "sangat tidak sehat"

\section{Rasio Cepat (Quick Ratio)}

Berikut rasio cepat Koperasi Karyawan Sejahtera Tahun 2012-2016 berdasarkan hasil perhitungan rasio seperti berikut ini:

Tabel 3. Rasio Cepat

\begin{tabular}{ll}
\hline Tahun & Rasio \\
\hline 2012 & $695,72 \%$ \\
2013 & $554,34 \%$ \\
2014 & $651,34 \%$ \\
2015 & $1058,12 \%$ \\
2016 & $1260,80 \%$ \\
\hline
\end{tabular}

Sumber: Data diolah

Berdasarkan Tabel 3 dapat dilihat quick ratio koperasi menunujukan angka antara 554\%-1260,8\% "sangat tidak sehat" walaupun asset lancar jauh lebih tinggi dibanding hutang jangka pendek, rasio ini tidak jauh berbeda dengan hasil current ratio. Rasionya masih sangat tinggi walaupun telah dikurangi persediaan karena jumlah persediaan yang dimiliki koperasi juga tidak banyak.

Dalam penelitian yang dilakukan oleh Roziqon (2016) hasil analisis rasio cepat (Quick Ratio) pada Koperasi Unit Desa Sumber Rezeki Desa Kepenuhan Raya yaitu sebesar 229\%, masuk standar "sehat".

\section{Rasio Kas (Cash Ratio)}

Berikut rasio kas Koperasi Karyawan Sejahtera RS. Islam Jakarta tahun 2012-2016 berdasarkan hasil perhitungan rasio berikut ini:

Tabel 4. Rasio Kas

\begin{tabular}{cc}
\hline Tahun & Rasio \\
\hline 2012 & $23,83 \%$ \\
2013 & $36,94 \%$ \\
2014 & $69,34 \%$ \\
2015 & $67,98 \%$ \\
2016 & $38,65 \%$ \\
\hline Sumber: Data diolah &
\end{tabular}

Berdasarkan Tabel 4 dapat dilihat cash ratio koperasi adalah hanya membandingkan kas \& uang yang ada di bank dengan hutang lancar, setiap tahun juga memperlihatkan ratio $(<125 \%)$ terindikasi "sangat tidak sehat" rasio tersebut mencerminkan bahwa setiap Rp1,-utang, untuk membayarnya dengan

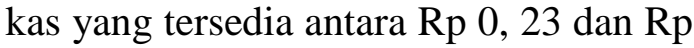
0,69 saja. Kas dan uang dibank sebagai aset paling likuid, yang dimiliki koperasi sangat sedikit sehingga angka rasio menunujukan ketidak mampuan dalam membayar/kesulitan dalam membayar hutang lancarnya.

Dalam penelitian yang dilakukan oleh Rachmawati (2013) cash ratio pada hasil penelitian Koperasi PRI Tegak tahun 2010-2012 menunjukkan rata-rata $33,88 \%$. Rasio ini lebih kurang sebanding dengan cash ratio Koperasi Sejahtera.

\section{Kinerja Keuangan Koperasi dari Aspek Rasio Solvabilitas}

Adapun rasio standar pengukuran debt to asset ratio berdasarkan Peraturan Koperasi berikut ini : 
Tabel 5. Standar Pengukuran DAR

\begin{tabular}{ll}
\hline Standar & Kriteria \\
\hline$\leq 40 \%$ & Sehat \\
$>40 \%$ s/d $50 \%$ & Cukup Sehat \\
$>50 \%$ s/d $60 \%$ & Kurang Sehat \\
$>60 \%$ s/d $80 \%$ & Tidak Sehat \\
$>80 \%$ & Sangat Tidak Sehat \\
\hline Sumber :PMK No.06/Per/M.KUKM/V/2006
\end{tabular}

Berikut DAR Koperasi Karyawan Sejahtera RS. Islam Jakarta tahun 20122016 berdasarkan hasil perhitungan rasio sebagai berikut:

Tabel 6. Kinerja Keuangan Berdasarkan DAR

\begin{tabular}{llr}
\hline Tahun & Rasio & Keterangan \\
\hline 2012 & $13,13 \%$ & Sehat \\
2013 & $17,44 \%$ & Sehat \\
2014 & $14,93 \%$ & Sehat \\
2015 & $9,25 \%$ & Sehat \\
2016 & $7,79 \%$ & Sehat \\
\hline
\end{tabular}

Sumber: Data diolah

Berdasarkan Tabel 6 dapat dilihat DAR koperasi selama lima tahun adalah 7,79\% s/d 17,44\%. Angka ini memenuhi kriteria standar "sehat" yaitu $\leq 40 \%$.

Penelitian yang dilakukan oleh Zulfany (2016) pada kinerja keuangan Koperasi Arrahmah selama kurun waktu 2012-2015 menghasilkan angka rasio DAR sebesar 91,135\%,indikator "sangat tidak sehat" jumlah hutang hampir sama dengan jumlah asset. Pada rasio DAR koperasi sejahtera mempunyai menunjukan kinerja yang lebih baik daripada koperasi Arrahmah. karena total hutang paling tinggi hanya $17 \%$ dari total asset, dalam kondisi terburuk, seandai nya koperasi di likuidasi maka secara hitungan aktiva tetap koperasi masih bisa direalisasikan jadi kas untuk melunasi hutang-hutang nya.

\section{Rasio total utang terhadap ekuitas sendiri}

Adapun standar pengukuran debt to equity ratio berdasarkan Peraturan Koperasi berikut ini :

Tabel 7. Standar Pengukuran DER

\begin{tabular}{ll}
\hline Standar & Kriteria \\
\hline$\leq 70 \%$ & Sehat \\
$>70 \%$ s/d 100\% & Cukup Sehat \\
$>100 \%$ s/d 150\% & Kurang Sehat \\
$>150 \%$ s/d 200\% & Tidak Sehat \\
$>200 \%$ & Sangat Tidak Sehat \\
\hline Sumber:PMK 06/Per/M.KUKM/V/2006
\end{tabular}

Berikut DER Koperasi Karyawan Sejahtera RS. Islam Jakarta tahun 20122016 berdasarkan hasil perhitungan rasio seperti berikut ini:

Tabel 8. Kinerja Keuangan Berdasarkan DER

\begin{tabular}{llc}
\hline Tahun & Rasio & Keterangan \\
\hline 2012 & $16,37 \%$ & Sehat \\
2013 & $22,88 \%$ & Sehat \\
2014 & $18,28 \%$ & Sehat \\
2015 & $10,59 \%$ & Sehat \\
2016 & $13,20 \%$ & Sehat \\
\hline Sumber: Data diolah
\end{tabular}

Berdasarkan Tabel 8 diatas diketahui bahwa koperasi selama lima tahun rasio utang terhadap ekuitas berada di angka 10,59\% s/d 22,88\% yang masuk dalam standar kriteria rasio "sehat" yaitu $\leq 70 \%$. Dengan kata lain, jumlah hutang ratio nya jauh dibawah ratio standar, tidak akan terancam di pailitkan, maka nya terpenuhi kategori "sehat".

Penelitian yang dilakukan oleh Zulfany (2016) pada kinerja keuangan Koperasi Arrahmah selama kurun waktu 2012-2015 menghasilkan angka rasio DER sebesar $779,04 \%$ yang berarti "sangat tidak sehat" menurut standar koperasi. 


\section{Kinerja Keuangan Koperasi dari Aspek Rasio Profitabilitas}

Adapun standar pengukuran net profit margin berdasarkan Peraturan Koperasi berikut ini :

Tabel 9. Standar Pengukuran NPM

\begin{tabular}{ll}
\hline Standar & Kriteria \\
\hline$\geq 15 \%$ & Sehat \\
$10 \% \mathrm{~s} / \mathrm{d}<15 \%$ & Cukup Sehat Kurang \\
$5 \% \mathrm{~s} / \mathrm{d}<10 \%$ & Sehat Tidak Sehat \\
$1 \% \mathrm{~s} / \mathrm{d}<5 \%$ & Sangat Tidak Sehat \\
$<1 \%$ & \\
\hline
\end{tabular}

Berikut net profit margin Koperasi Karyawan Sejahtera RS. Islam Jakarta tahun 2012-2016 berdasarkan hasil perhitungan rasio sebagai beriku:

Tabel 10. Kinerja Keuangan Berdasarkan NPM

\begin{tabular}{lll}
\hline Tahun & Rasio & Keterangan \\
\hline 2012 & $3,41 \%$ & Tidak Sehat \\
2013 & $3,33 \%$ & Tidak Sehat \\
2014 & $2,88 \%$ & Tidak Sehat \\
2015 & $2,92 \%$ & Tidak Sehat \\
2016 & $3,06 \%$ & Tidak Sehat
\end{tabular}

Sumber: Data diolah

Berdasarkan Tabel 10 dapat dilihat Net Profit Margin koperasi adalah 2,88\% s/d 3,41\%, angka ini menunjukan indikator"tidak Sehat" Rasio ini menginformasikan bahwa sangat kecil kemampuan koperasi dalam menghasilkan SHU/laba Usaha, karena angka nya jauh dibawah standar yaitu $15 \%$.

Penelitian yang dilakukan oleh Zulfany (2016) pada koperasi Arrahmah menghasilkan rata-rata Net Profit Margin pada tahun 2012-2015 juga menunjukan ratio $6,34 \%$ kemampuan nya menghasilkan
SHU juga masih rendah dibanding dengan standar akan tetapi Koperasi Sejahtera menunjukan angka rentabilitas yang jauh lebih kecil daripada koperasi Arrahmah.

\section{Return on Assets (ROA)}

Adapun standar pengukuran ROA berdasarkan Peraturan Koperasi berikut ini:

Tabel 11. Standar Pengukuran ROA

\begin{tabular}{ll}
\hline Standar & Kriteria \\
\hline$\geq 10 \%$ & Sehat \\
$7 \% \mathrm{~s} / \mathrm{d}<10 \%$ & Cukup Sehat \\
$3 \% \mathrm{~s} / \mathrm{d}<7 \%$ & Kurang Sehat \\
$1 \% \mathrm{~s} / \mathrm{d}<3 \%$ & Tidak Sehat \\
$<1 \%$ & Sangat Tidak Sehat \\
\hline Sumber: PMK No.06/Per/M.KUKM/V/2006
\end{tabular}

Berikut rasio ROA Koperasi Karyawan Sejahtera RS. Islam Jakarta tahun 2012-2016 berdasarkan hasil perhitungan rasio berikut ini:

Tabel 12. Kinerja Keuangan Berdasarkan ROA

\begin{tabular}{lll}
\hline Tahun & Rasio & Keterangan \\
\hline 2012 & $1,14 \%$ & Tidak Sehat \\
2013 & $1,3 \%$ & Tidak Sehat \\
2014 & $1,28 \%$ & Tidak Sehat \\
2015 & $1,27 \%$ & Tidak Sehat \\
2016 & $1,17 \%$ & Tidak Sehat \\
\hline
\end{tabular}

Sumber: Data diolah

Berdasarkan Tabel 12 dapat dilihat Return On Asset koperasi adalah $1,14 \% \mathrm{~s} / \mathrm{d} 1,3 \%$, adalah ratio yang "tidak sehat" menurut standar ROA koperasi.

Penelitian yang dilakukan oleh Zulfany (2016) pada koperasi Arrahmah menghasilkan rata-rata Return On Asset dari tahun 2012-2015 juga memperlihatkan angka $1,2 \%$ yang berarti mempunyai ratio ROA yang kurang lebih sama. 


\section{Return on Equity (ROE)}

Adapun standar pengukuran return on equity berdasarkan Peraturan Koperasi berikut ini :

Tabel 13. Standar Pengukuran ROE

\begin{tabular}{ll}
\hline Standar & Kriteria \\
\hline$\geq 21 \%$ & Sehat \\
$15 \%$ s/d $<21 \%$ & Cukup Sehat \\
$9 \%$ s/d $<15 \%$ & Kurang Sehat \\
$3 \%$ s/d $<9 \%$ & Tidak Sehat \\
$<3 \%$ & Sangat Tidak Sehat \\
\hline \multicolumn{2}{l}{ Sumber: PMK No.06/Per/M.KUKM/V/2006 }
\end{tabular}

Berikut rasio ROE Koperasi Karyawan Sejahtera Tahun 2012-2016 berdasarkan hasil perhitungan rasio adalah:

Tabel 14. Kinerja Keuangan Berdasarkan ROE

\begin{tabular}{ccc}
\hline Tahun & Rasio & Keterangan \\
\hline 2012 & $1,42 \%$ & Sangat Tidak Sehat \\
2013 & $1,70 \%$ & Sangat Tidak Sehat \\
2014 & $1,57 \%$ & Sangat Tidak Sehat \\
2015 & $1,45 \%$ & Sangat Tidak Sehat \\
2016 & $1,98 \%$ & Sangat Tidak Sehat \\
\hline
\end{tabular}

Sumber: Data diolah

Berdasarkan Tabel 14 dapat dilihat Return On Equity koperasi adalah $1,42 \%$ s/d 1,98\%, terindikasi "sangat tidak sehat" Ratio ini memperlihatkan angka yang jauh lebih kecil jika melihat pada ratio standar "sehat" adalah diatas $21 \%$.

Penelitian yang dilakukan oleh Zulfany (2016) pada koperasi Arrahmah menghasilkan rata-rata Return On Equity dari tahun 2012-2015 adalah 13,48\%, sehingga berada di kriteria "kurang sehat, tetapi jauh lebih baik daripada koperasi sejahtera yang ROE nya tidak sampai $2 \%$.
Hal ini menunjukkan kinerja keuangan Koperasi Sejahtera menggambarkan kinerja kemampuan menghasilkan laba/ SHU sangat rendah ,bahkan jauh dibawah tingkat bunga pasar.

\section{Kinerja Keuangan Koperasi dari Aspek Rasio Aktivitas}

Rasio aktivitas meliputi rasio perputaran piutang atau Receivable Turn Over yang mengukur berapa kali piutang ditagih menjadi kas selama 1 tahun, dihitung dengan rumus berikut : Pendapatan dibagi Rata-Rata piutang, dan rata-rata piutang dihitung dengan piutang awal periode + piutang akhir periode di bagi dua.

Adapun standar pengukuran perputaran piutang berdasarkan Peraturan Koperasi pada Tabel 15 berikut ini :

Tabel 15. Standar Pengukuran Perputaran Piutang

\begin{tabular}{ll}
\hline Standar & Kriteria \\
\hline$\geq 12$ kali & Sehat \\
10 kali s/d $<12$ kali & Cukup Sehat \\
8 kali s/d $<10$ kali & Kurang Sehat \\
6 kali s/d $<8$ kali & Tidak Sehat \\
$<6$ kali & Sangat Tidak Sehat \\
\hline Sumber:PMK No.06/Per/M.KUKM/V/2006
\end{tabular}

Berikut rasio perputaran piutang Koperasi Karyawan Sejahtera RS. Islam Jakarta tahun 2012-2016 berdasarkan hasil perhitungan rasio berikut ini:

Tabel 16. Kinerja Keuangan Berdasarkan Perputaran Piutang

\begin{tabular}{lll}
\hline Tahun & Rasio & Keterangan \\
\hline 2012 & 0,43 kali & Sangat Tidak Sehat \\
2013 & 0,49 kali & Sangat Tidak Sehat \\
2014 & 0,53 kali & Sangat Tidak Sehat \\
2015 & 0,51 kali & Sangat Tidak Sehat \\
2016 & 0,41 kali & Sangat Tidak Sehat \\
\hline Sumber: Data diolah &
\end{tabular}


Berdasarkan Tabel 16 di atas diketahui bahwa koperasi selama lima tahun rasio Receible Turnover berada di angka 0,43 kali s/d 0,53 kali yang menunjukan angka perputaran piutang sangat lambat,yaitu "sangat tidak sehat" karena standar nya lebih dari 12 kali itu yang masuk kategori "Sehat".

Penelitian yang dilakukan oleh Aprilia (2014) pada Koperasi Dhaya Harta Jombang menghasilkan rata- rata rasio perputaran piutang pada tahun 2007-2011 adalah 0,13 kali.Koperasi Sejahtera memiliki Receible Turnover yang lebih tinggi dibandingkan dengan hasil penelitian terdahulu, akan tetapi tetap berada di bawah standar rasio keuangan koperasi. Hal ini menunjukkan kinerja keuangan koperasi yang menggambarkan piutang sangat rendah perputarannya.

\section{Rasio Likuiditas, Solvabilitas, Profitabilitas, dan Aktivitas Terhadap Kinerja Keuangan}

Berdasarkan hasil penelitian terhadap Rasio: Likuiditas, Solvabilitas, Profitabilitas, dan Aktivitas Untuk Menilai Kinerja Keuangan Pada Koperasi Sejahtera Tahun 2012-2016. Ratio likuiditas adalah untuk mengukur kemampuan koperasi dalam membayar hutang jangka pendek, dan ratio solvabilitas adalah hutang keseluruhan, jangka pendek dan jangka panjang. Hasil perhitungan pada Tabel 2,3,4 sebagai Ratio dalam mengukur Likuiditas semua nya terindikasi "Tidak Sehat" secara hitungan ekonomi, karena jumlah hutang kecil, tetapi jumlah piutang terlalu besar dan lama jangka waktu penagihannya, disamping itu jumlah persediaan barang dagangan juga kecil jumlahnya, yang berarti kemampuan koperasi membayar hutang jangka pendek adalah rendah atau lemah. Jika dikaji ratio solvabilitas yaitu untuk mengukur kemampuan koperasi dalam membayar total hutang nya, menunjukan ratio "Sehat" karena total hutang dibanding dengan total aktiva dan total Equiti. Jika dikaji dengan teliti, dengan memperhatikan akun account Receivable atau piutang pada anggota koperasi merupakan bagian terbesar harta lancar dan piutang ini berada pada posisi umur piutang yang sudah lama belum bisa ditagih, sehingga tidak memenuhi fungsi nya sebagai aset lancar, hal ini menjadi penyebab rasio likuiditas "tidak sehat" masalah ini yang dominan menjadi penyebab ratio likuiditas dan ratio solvabilitas tidak memenuhi standar ketentuan koperasi. Sekaligus kondisi ini menjadi penghalang untuk mencapai tujuan koperasi untuk mensejahterakan anggota nya dengan indiator Sisa Hasil Usaha/SHU yang sangat minim/jauh dibawah standar.

Ratio Profitabilitas yang diukur dengan NPM, ROA \& ROE yaitu membandingkan SHU dengan: Pendapatan, Total Aktiva \& Modal Koperasi yang di jelaskan pada Tabel 10, 12 dan 14 selama tahun 2012-2016 semua nya memperlihatkan perhitungan "Tidak Sehat" semua indikator berada jauh dibawah angka yang ditetapkan dalam standar profitabilitas koperasi, fakta rasio profitabilitas yang minim mengindikasikan bahwa hasil kegiatan koperasi sejahtera belum sesuai dengan tujuan untuk mensejahterakan anggota nya, berarti ada masalah dalam pengelolaan kegiatan operasional oleh manajemen nya yang harus diperbaiki. Analisis ini juga di dukung dengan data dari ratio aktivitas yang dikemukakan dalam Tabel 16 yang juga menunjukan indikator "Sangat Tidak Sehat". Sumber daya baik berupa sumber dana maupun sumber daya manusia yang ada, belum didaya gunakan belum dapat 
dimanfaatkan/dikelola dengan cara-cara yang efektif untuk mencapai tujuan, sehingga dapat memberikan keuntungan atau meningkatkan kesejahteraan bagi seluruh anggota koperasi.

\section{PENUTUP}

Kinerja keuangan pada Koperasi Sejahtera Karyawan Rumah Sakit Swasta di Jakarta Pusat Tahun 2012-2016 berdasarkan rasio likuditas, profitabilitas dan aktivitas menunjukkan sangat tidak sehat sedang rasio solvabilitas menunjukan indikator sehat.

\section{DAFTAR PUSTAKA}

Aprilia, A. 2014. Analisis Rasio Keuangan Untuk Mengukur Kinerja Keuangan Pada Koperasi Dhaya Harta Jombang. Jurnal Ilmu \& Riset Manajemen Sekolah Tinggi Ilmu Ekonomi Indonesia (STIESIA) Surabaya. Vol. 3 No. 2

Fahmi, I. 2014. Analisis Laporan Keuangan. Bandung: Alfa Betha

Horne, V., James C. dan Wachowicz, Jr., Jhon M. 2012. Prinsip-prinsip Manajemen Keuangan Edisi 13. Jakarta: Salemba Empat
Jumingan. 2011. Analisis Laporan Keuangan. Jakarta: Bumi Aksara

Kemkop dan UKM Beri Nilai Tambah Bagi Pelaku UKM, http://www.beritasatu.com/nasional 1362157-kemkop-danukmberinilaitambahbagi-pelakuukm.html. Diakses 16 Juli 2018.

Rachmawati, RP. 2013. Analisis Laporan Keuangan Untuk Menilai Kinerja Keuangan Koperasi Pegawai Republik Indonesia (KPRI) Tegak Kecamatan Sentolo Kulon Pogo. Skripsi S1. Universitas Negeri Yogyakarta

Roziqon, M. 2016. Analisis Rasio Likuiditas Pada Koperasi Unit Desa Sumber Rezeki Desa Kepenuhan Raya. E-Jurnal Ekonomi Universitas Pasir Pengaraian.

Subramanyam, K.R., Wild, J. 2010. Analisis Laporan Keuangan Edisi 10. Jakarta: Salemba Empat

Sugiyono. 2012. Metode Penelitian Bisnis. Bandung: Alfabeta

Zulfany, MR. 2016. Analisis Rasio Keuangan Untuk Menilai Kinerja Keuangan Koperasi Syariah (Studi Kasus Pada Koperasi SPPS Arrahmah Cinere). Skripsi S1. Universitas Islam Negeri Jakarta. 